\title{
Drug-induced interstitial lung disease
}

\author{
Citation for published version (APA):
}

Jessurun, N. T., Drent, M., van Puijenbroek, E. P., Bekers, O., Wijnen, P. A., \& Bast, A. (2019). Druginduced interstitial lung disease: role of pharmacogenetics in predicting cytotoxic mechanisms and risks of side effects. Current Opinion in Pulmonary Medicine, 25(5), 468-477.

https://doi.org/10.1097/MCP.0000000000000590

Document status and date:

Published: 01/09/2019

DOI:

10.1097/MCP.0000000000000590

Document Version:

Publisher's PDF, also known as Version of record

Document license:
Taverne

Please check the document version of this publication:

- A submitted manuscript is the version of the article upon submission and before peer-review. There can be important differences between the submitted version and the official published version of record.

People interested in the research are advised to contact the author for the final version of the publication, or visit the DOI to the publisher's website.

- The final author version and the galley proof are versions of the publication after peer review.

- The final published version features the final layout of the paper including the volume, issue and page numbers.

Link to publication

\footnotetext{
General rights rights.

- You may freely distribute the URL identifying the publication in the public portal. please follow below link for the End User Agreement:

www.umlib.nl/taverne-license

Take down policy

If you believe that this document breaches copyright please contact us at:

repository@maastrichtuniversity.nl

providing details and we will investigate your claim.
}

Copyright and moral rights for the publications made accessible in the public portal are retained by the authors and/or other copyright owners and it is a condition of accessing publications that users recognise and abide by the legal requirements associated with these

- Users may download and print one copy of any publication from the public portal for the purpose of private study or research.

- You may not further distribute the material or use it for any profit-making activity or commercial gain

If the publication is distributed under the terms of Article $25 \mathrm{fa}$ of the Dutch Copyright Act, indicated by the "Taverne" license above, 


\title{
Drug-induced interstitial lung disease: role of pharmacogenetics in predicting cytotoxic mechanisms and risks of side effects
}

\author{
Naomi T. Jessurun ${ }^{\mathrm{a}, \mathrm{b}}$, Marjolein Drent ${ }^{\mathrm{b}, \mathrm{c}, \mathrm{d}}$, Eugène P. van Puijenbroek ${ }^{\mathrm{a}, \mathrm{e}}$, \\ Otto Bekers $^{\mathrm{b}, \mathrm{f}}$, Petal A. Wijnen ${ }^{\mathrm{b}, \mathrm{f}}$, and Aalt Bast ${ }^{\mathrm{b}, \mathrm{c}, \mathrm{g}}$
}

\begin{abstract}
Purpose of review
The diagnosis of drug-induced interstitial lung disease (DI-ILD) is challenging and mainly made by exclusion of other possible causes. Toxicity can occur as a cause of drug(s) or drug-drug interactions. In this review, we summarize the possible role of pharmacogenetics of metabolizing enzymes in DI-ILD.
\end{abstract}

\section{Recent findings}

Knowledge of the genetic predispositions of enzymes involved in drug metabolization and their relation with proposed cytotoxic mechanisms of DI-ILD, in particular direct cell toxicity and free oxygen radical production is increasing. The cytochrome P450 enzyme family and other enzymes play an important role in the metabolism of all sorts of ingested, injected, or inhaled xenobiotic substances. The liver is the major site for metabolism. Metabolic cytotoxic mechanisms have however also been detected in lung tissue. Polymorphisms in genes coding for enzymes that influence metabolic activity may lead to localized (toxic) reactions and tissue damage. This knowledge may be helpful in preventing the risk of DI-ILD.

\section{Summary}

Drug toxicity can be the consequence of absence or very poor enzyme activity, especially if no other metabolic route is available. In the case of reduced enzyme activity, it is recommended to reduce the dose or to prescribe an alternative drug, which is metabolized by a different, unaffected enzyme system to prevent toxic side effects. However, enhanced enzyme activity may lead to excessive formation of toxic and sometimes reactive metabolites. Therefore, knowing a patient's drug-metabolizing profile before drug prescription is a promising way to prevent or explain DI-ILD.

\section{Keywords}

adverse drug reactions, cytochrome P450, cytotoxic mechanisms, drug metabolizing enzymes, drug-induced pneumonitis, glucose-6-phosphate dehydrogenase, polymorphisms, thiopurine S-methyltransferase, xenobiotics

\section{INTRODUCTION}

Diffuse or interstitial lung diseases (ILD) can involve various patterns and the causes vary $\left[1^{-"}, 2^{-"}\right]$. An ever increasing number of drugs can produce variegated patterns of ILD, virtually all histopathologic patterns of interstitial pneumonia, including cellular and fibrotic nonspecific interstitial pneumonia, pulmonary infiltrates, and eosinophilia (PIE), organizing pneumonia, lymphocytic interstitial pneumonia, desquamative interstitial pneumonia (a condition in which both the interstitium and the alveolar space are involved), a pulmonary granulomatosis-like reaction, and a common interstitial pneumonia-like pattern [3]. Moreover, the presentation can be more or less subclinical, with only an alveolitis pattern in the

\begin{abstract}
aNetherlands Pharmacovigilance Centre Lareb, 's-Hertogenbosch, The Netherlands, bILD Care Foundation Research Team, Ede, The Netherlands, 'Department of Pharmacology and Toxicology, Faculty of Health, Medicine and Life Science, Maastricht University, Maastricht, The Netherlands, ILD Center of Excellence, St. Antonius Hospital, Nieuwegein, The Netherlands, ${ }^{e}$ Groningen Research Institute of Pharmacy, University of Groningen, Groningen, The Netherlands, 'Department of Clinical Chemistry, Central Diagnostic Laboratory, Maastricht University Medical Centre, Maastricht, The Netherlands and ${ }^{9}$ Venlo Campus, Maastricht University, Venlo, The Netherlands
\end{abstract}

Correspondence to Aalt Bast, Venlo Campus Maastricht University, P.O. Box 8, 5900 AA Venlo, The Netherlands. Tel: +31 43 3883195; fax: +31 43388 4146; e-mail: a.bast@maastrichtuniversity.nl

Curr Opin Pulm Med 2019, 25:468-477

DOI:10.1097/MCP.0000000000000590 


\section{KEY POINTS}

- Drugs are underestimated serious causative agents of interstitial lung disease.

- The variability in drug response among patients is multifactorial.

- Genetic variations in metabolizing enzymes are able to enhance the drivers of drug-induced interstitial lung disease.

- Both clinical and genetic risk stratification (pharmacogenomics) may lead to a more accurate prevention of drug-induced lung damage in the future.

- Current and future reports regarding the association of certain gene variants with progression and/or deterioration in interstitial pneumonias should be validated before utilization in patients' management.

cellular profile of bronchoalveolar lavage fluid (see also Fig. 1) [4]. Moreover, drug-induced pulmonary toxicity can present with varying patterns on chest computed tomography imaging (see also Fig. 2). Drugs in one therapeutic class may collectively produce the same pattern of involvement. Few drugs are known to produce more than one pattern of ILD [5]. The diagnosis of drug-induced ILD (DI-ILD) essentially rests on the temporal association between exposure to the drug and the development of pulmonary infiltrates. Thus, the diagnosis of DI-ILD is mainly made by the meticulous exclusion of all other possible causes $[4,6]$. The striking individual susceptibility for drug-induced lung injury, however, suggests a genetic background. Increased understanding

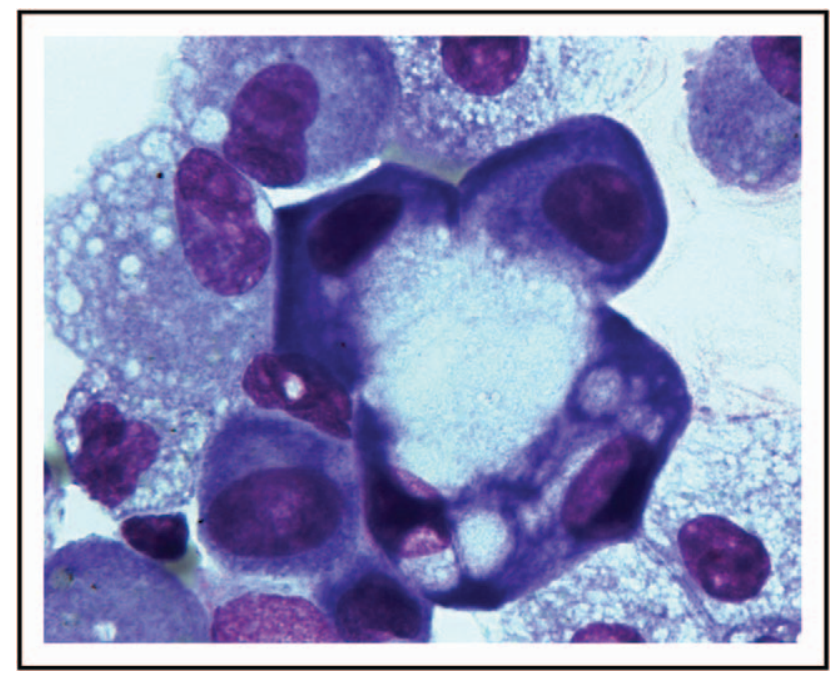

FIGURE 1. Reactive pneumocyte type II cell (central) present in bronchoalveolar lavage fluid of a patient with cocaine DI-ILD (see also Figure 2).

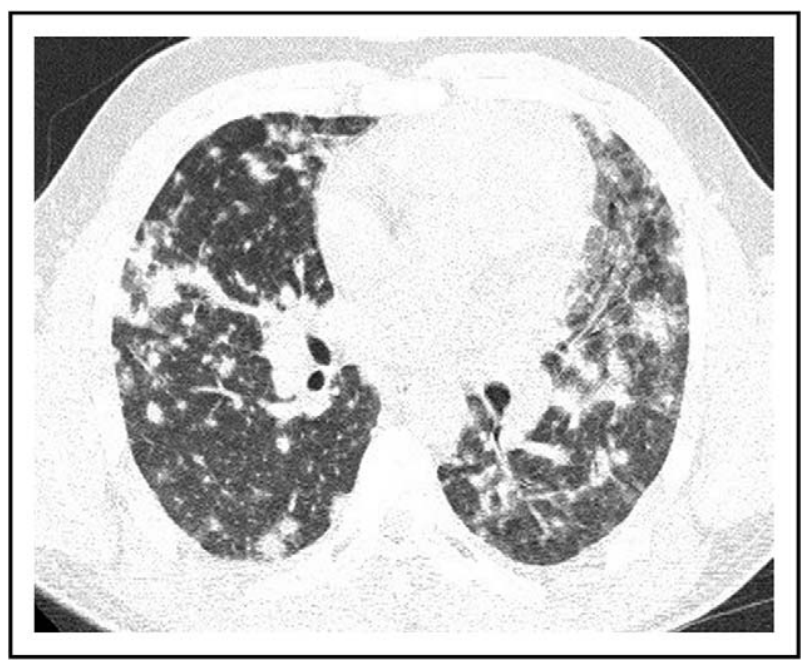

FIGURE 2. High-resolution computed tomography scan through the midlung zones shows scattered ill-defined nodulas and ground-glass opacity in the lingular segment of a patient with cocaine-induced ILD (a carrier of CYP2C and VKORC 1 variant alleles).

of the genetic predispositions of enzymes involved in drug metabolization and their relation with proposed cytotoxic mechanisms of drug-induced lung injury, in particular direct cell toxicity and free oxygen radical production, offers the possibility to prevent the frequently serious DI-ILD from occurring [7].

\section{MECHANISMS OF DRUG-INDUCED LUNG INJURY}

Both cytotoxic and immune mechanisms may be involved independently or in combination, in the initiation and propagation of DI-ILD [8]. The lungs have the potential of metabolizing many foreign compounds, including pharmaceutical products. The so-called biotransformation is the process by which cells modify xenobiotics with the ultimate goal of facilitating the elimination of lipophilic substances. To increase the water solubility of xenobiotics, a broad set of enzymes capable of introducing new functional groups (phase I) or conjugating with internal cell's molecules (phase II) is involved. Sometimes, however, these enzymes transform an otherwise harmless product in a reactive intermediate, a process called bioactivation (Fig. 3). Biotransformation can result in the formation of reactive electrophilic species such as epoxides, quinones, quinoneimines, methylene-imines, and acyl radicals which react with cell biomolecules, modifying them or forming covalent adducts and causing direct cell toxicity [9]. In addition to this mechanism, the production of free oxygen radicals and alteration of the oxidant-antioxidant balance is one of the mechanisms (Fig. 3) of iatrogenic pneumonitis [10]. Redox 


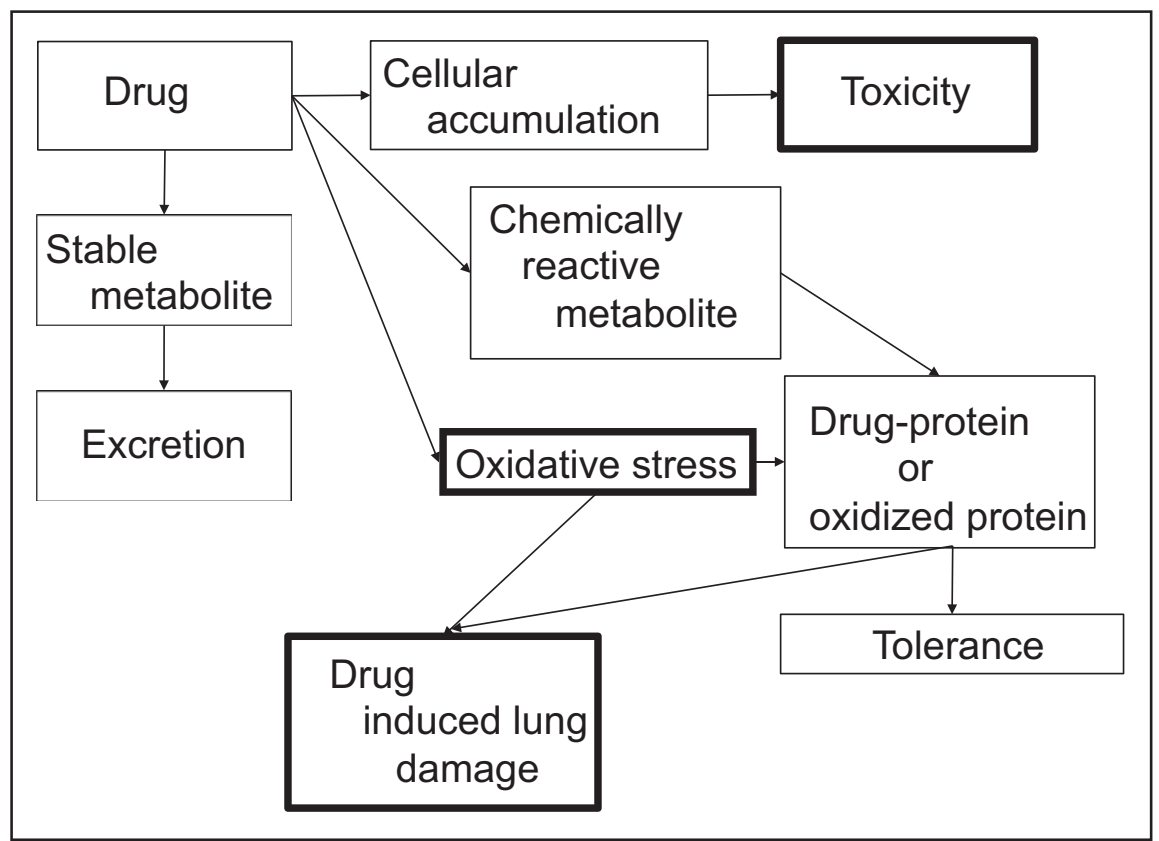

FIGURE 3. Overview of molecular mechanisms leading to drug-induced lung damage. Drugs are enzymatically degraded to stable metabolites (e.g. via cytochrome P450) and excreted. A decreased metabolic activity may cause accumulation of drugs, which may lead to toxicity. Biotransformation may also lead to the formation of chemically reactive metabolites. These metabolites (haptens) can form an adduct with proteins. This leads to tolerance or (sometimes), in combination with a costimulatory signals (e.g. oxidative stress, or a viral or bacterial infection) to a toxic immune reaction and subsequent lung damage [15']. Finally, there are strong indications that oxidative stress, for example via redox cycling of drugs, is involved in drug-induced lung damage.

cycling leads to the formation of superoxide anion free radicals $\left(\mathrm{O}_{2}{ }^{--}\right)$, which may transform into other reactive oxygen species (ROS) such as $\mathrm{H}_{2} \mathrm{O}_{2}$ and $\bullet \mathrm{OH}$ (Fig. 3) $[8,11]$. These ROS may directly or indirectly lead to lung damage. Interestingly, direct activation of lung fibroblasts is initiated via the influx of superoxide anion radicals through chloride channels. Activated fibroblasts result in the production of transforming growth factor beta-1 and collagen [12]. This finding makes it conceivable that redox cycling drugs lead to lung fibrosis. A similar mechanism has been suggested to occur in hepatic stellate cells, which has led to the suggestion that this may lead to liver fibrosis [13]. The noncommercial website Pneumotox provides a list of drugs that have shown or suggested to cause lung damage [14]. The website ranks the reported cases by 1-5 stars ranging, indicating the degree of plausibility that the drug is causative for lung damage.

\section{ENZYMES WITH GENETIC VARIATION AND INVOLVEMENT IN DRUG METABOLIZATION POSSIBLY LEADING TO INTERSTITIAL LUNG DISEASE}

There are more than 30 families of drug-metabolizing enzymes in humans. Essentially all of the major human enzymes responsible for modifications of functional groups (phase I) or conjugation with endogenous substituents (phase II) exhibit common polymorphisms at the genomic level, many of which translate into functional changes in the encoded proteins and thereby determine the efficacy and toxicity of medications. In many cases, a polymorphism is associated with reduced activity of the encoded protein (e.g. glucose-6-phosphate dehydrogenase, G6PD), but there are also examples where the allelic variant encodes proteins with enhanced activity (e.g. CYP iso-enzyme 2C19*17) [16,17]. It is now well recognized that adverse drug reactions may be caused by specific drug-metabolizer phenotypes, such as severe and potentially fatal hematopoietic toxicity that occurs when thiopurine methyltransferase-deficient patients are treated with standard dose of the thiopurines, azathioprine or 6-mercaptopurine [18]. Another example is dihydropyrimidine dehydrogenase deficiency and 5-fluorouracil toxicity leading to hematological and gastrointestinal toxicities [19]. A large number of associations have been identified between drug-induced toxicity and genetic variations in their metabolizing enzymes [20]. The focus in this review, however, is on drug-genetic variant enzyme combinations, which are most important for the causation of DI-ILD. 
Considering the mechanisms of lung injury and the (by-)products of drug metabolization, it is expected that polymorphism(s) of metabolizing enzymes enhancing or leading to the formation of reactive drug metabolites and ROS, may increase the chances of the occurrence of DI-ILD. In this review, the current state of research on the association between genetic variations in phase I and phase II enzymes involved in drug metabolization and their distinct role in the mechanisms of drug-induced lung damage is assessed and merged. The results of the analysis are summarized in Table 1. Except for the enzymes belonging to the CYP superfamily, most polymorphisms, lead to enzyme deficiencies. In the sections later, involvement of polymorphisms of G6PD, CYP and thiopurine S-methyltransferase (TPMT) in DI-ILD are further explored. Some clinical cases are included as an example.

\section{GLUCOSE-6-PHOSPHATE DEHYDROGENASE}

A single genotype seems to play a crucial role in the protection against ROS-induced lung damage, viz. G6PD, a critical enzyme in the pentose phosphate pathway. In this pathway a supply of NADPH is generated via the G6PD catalyzed conversion of glucose-6-phosphate to 6-phosphogluconolactone. $\mathrm{NADPH}$ is necessary for adequate generation of protective intracellular thiols, which are needed to protect against the damaging effects of ROS. An important protective thiol is the tripeptide glutathione (GSH). GSH itself is an antioxidant and acts as a cofactor in glutathione dependent antioxidant enzymes [21,22]. A diminished activity of G6PD thus increases the risk of a lack of intracellular antioxidant protection, and increases oxidative stress because it hampers the regeneration of the reduced protective form of GSH (Fig. 4).

In many cases clinical manifestations of G6PD deficiency will not be observed. Other antioxidants such as mitochondrial antioxidant systems will take over the protection against ROS. Erythrocytes lack mitochondria and thus strongly depend on the cytosolic pentose phosphate pathway for NADPH and are therefore particularly vulnerable for oxidative damage in case of G6PD deficiency. Hemolytic anemia may be the result. Other tissues besides erythrocytes may also become damaged more easily in cases of oxidative stress. This can be a direct ROS damage or an indirect damage via the toxicity of iron, which is known to cause a fibrotic interstitial trigger in lung tissue. G6PD deficiency is a very common enzymopathy and is estimated to affect 400 million people especially in areas in Africa [23]. It is thought that G6PD deficiency offered an evolutionary advantage because it weakens the erythrocyte membrane, the host cell of the malaria parasite (Plasmodium falciparum). This makes it difficult for the parasite to have productive growth in the erythrocyte. Numerous medications and some oxidative food products like fava beans (Vicia faba) should be avoided by G6PDdeficient patients.

Redox cycling compounds generate superoxide anion radicals and subsequently various other ROS. Redox cycling compounds include the antibiotic nitrofurantoin, the cytostatic bleomycin (which is even used as model compound in animal or cell research to reliably induce pulmonary fibrosis), cocaine, and the antimalarial drug primaquine (Table 1) [24-27].

ILD induced by redox cycling drugs is based on this mechanism and G6PD deficiency, by increased oxidative stress, could increase the occurrence of ILD. Widely used drugs that should be avoided in G6PD deficiency are associated with DI-ILD (Table 2) [28]. Figure $5 \mathrm{a}$ and $\mathrm{b}$ show an example of DI-ILD: a case of nitrofurantoin induced pneumonitis.

\section{CYTOCHROME P450 ENZYMES}

Members of the CYP family are responsible for the metabolism of endogenous substrates, and for pharmaceuticals. CYP enzymes are involved in the biotransformation of chemicals like drugs. CYP activity frequently (but not always!) reduce or alter the pharmacological activity of many drugs while facilitating their elimination. The CYP enzymes are largely polymorphic and variant alleles together with host and environmental factors result in, normal (extensive metabolizer, EM), increased (ultrarapid metabolizer), decreased (intermediate metabolizer), or no enzyme activity (poor metabolizer), and thus four possible metabolizing phenotypes. Therefore, an ultra-rapid metabolizer phenotype leads to accelerated drug metabolism of the parent drug resulting in low parent drug serum levels accompanied by sometimes less efficacy and the formation of (in)active and even toxic or reactive metabolites. intermediate metabolizer and poor metabolizer phenotypes lead to the accumulation of the parent drug, or a push to another sometimes less favorable metabolization pathway [29]. Because the various CYP enzymes have different metabolic activity and are not evenly distributed in organs, knowledge on the characteristics of CYP enzymes in the lung and drug metabolism pathways may have value in recognizing the causative agent in patients presenting with DI-ILD [20]. The most important enzymes for drug metabolism are CYP1A2 $(+)$, CYP2C9 $(++)$, CYP2D6 $(++)$, CYP3A4 $(+++)$, and CYP3A5 $(+++)$. Their presence in the lung is noted 
Table 1. Drug metabolizing enzymes, drugs metabolized by these enzymes and the current state of information of their relation with ILD

\begin{tabular}{|c|c|c|c|c|c|}
\hline $\begin{array}{l}\text { Enzymes involved in } \\
\text { drug metabolism }\end{array}$ & $\begin{array}{l}\text { Polymorphisms } \\
\text { phenotype }\end{array}$ & $\begin{array}{l}\text { Drugs } \\
\text { metabolized by } \\
\text { the particular } \\
\text { enzymes }\end{array}$ & $\begin{array}{l}\text { Proposed } \\
\text { mechanism of } \\
\text { causing } \\
\text { pulmonary } \\
\text { toxicity }\end{array}$ & $\begin{array}{l}\text { All if available: } \\
\text { Rating in } \\
\text { Pneumotox [14] } \\
{ }^{*}<10 \text { cases; } \\
{ }^{* *} 10-50 \text { cases; } \\
{ }^{* * *} 50-100 \text { cases; }{ }^{* * * *} \\
100-200 \text { cases; } \\
{ }^{* * * * *}>200 \text { cases }\end{array}$ & $\begin{array}{l}\text { Quality of the studies } \\
\text { (very low - high) } \\
\text { n/a = not included in } \\
\text { the latest systematic } \\
\text { review [ } 1^{\text {"-n }} \text { ] }\end{array}$ \\
\hline \multicolumn{6}{|l|}{ Phase I enzymes } \\
\hline $\begin{array}{l}\text { Glucose-6-phosphate } \\
\text { dehydrogenase } \\
\text { (G6PD) }\end{array}$ & Decreased activity & $\begin{array}{l}\text { Nitrofurantoin } \\
\text { Cocaine } \\
\text { Primaquine } \\
\text { Flutamide } \\
\text { Dapsone } \\
\text { Sulfacetamide }\end{array}$ & $\begin{array}{l}\text { Generation of free oxygen } \\
\text { radicals [1 1 ] }\end{array}$ & $\begin{array}{l}* * * * * \\
* * * * * \\
* \\
* \\
* * \\
*\end{array}$ & $\begin{array}{l}\text { Low } \\
n / a \\
n / a \\
n / a \\
n / a \\
n / a\end{array}$ \\
\hline Cytochrome P450 & & & $\begin{array}{l}\text { Release of toxic oxygen } \\
\text { radicals } \\
\text { and reactive metabolites } \\
\text { [7] }\end{array}$ & & \\
\hline CYP2D6 & $\begin{array}{l}\text { Decreased } \\
\text { (poor and intermediate } \\
\quad \text { metabolizer) } \\
\text { Increased function } \\
\text { (rapid metabolizer) }\end{array}$ & Tamoxifen & & * & $n / a$ \\
\hline CYP3A & & $\begin{array}{l}\text { Acetaminophen } \\
\text { Amiodaron } \\
\text { Dasatinib } \\
\text { Fentanyl } \\
\text { Fluticasone } \\
\text { Imatinib } \\
\text { Sirolimus } \\
\text { Everolimus } \\
\text { Erlotinib } \\
\text { Gefitinib } \\
\text { Methadone }\end{array}$ & & $\begin{array}{l}* * * \\
* * * * * \\
* * * * \\
* * * * * \\
* * * * \\
* * * \\
* * * * \\
* * * * * \\
{ }^{* * *} \\
{ }^{* * * * *} \\
* * * * *\end{array}$ & $\begin{array}{l}\mathrm{n} / \mathrm{a} \\
\text { Very low - low } \\
\mathrm{n} / \mathrm{a} \\
\mathrm{n} / \mathrm{a} \\
\mathrm{n} / \mathrm{a} \\
\text { Low } \\
\text { Very low } \\
\text { Very low - moderate } \\
\text { Low-moderate } \\
\text { Low-moderate } \\
\mathrm{n} / \mathrm{a}\end{array}$ \\
\hline $\begin{array}{l}\text { CYP2C8 } \\
\text { CYP2C9 } \\
\text { CYP2C19 }\end{array}$ & $\begin{array}{l}\text { Decreased activity } \\
\text { Decreased activity } \\
\text { Decreased activity }\end{array}$ & $\begin{array}{l}\text { Amiodaron } \\
\text { Paclitaxel } \\
\text { Cyclophosphamide } \\
\text { Warfarine }\end{array}$ & & $\begin{array}{l}* * * * * \\
* * * * * \\
* * * * \\
* *\end{array}$ & $\begin{array}{l}\text { Very low - low } \\
\mathrm{n} / \mathrm{a} \\
\mathrm{n} / \mathrm{a} \\
\mathrm{n} / \mathrm{a}\end{array}$ \\
\hline $\begin{array}{l}\text { Dihydropyrimidine } \\
\text { dehydrogenase (DPD) }\end{array}$ & Decreased activity & $\begin{array}{l}\text { 5-FU } \\
\text { capecitabine }\end{array}$ & $\begin{array}{l}\text { Decreased detoxification of } \\
\text { pyrimidine-based } \\
\text { antimetabolite } \\
\text { analogues [15 }\left[15^{\mathbf{p}}\right.\end{array}$ & $\begin{array}{l}* * * \\
*\end{array}$ & $n / a$ \\
\hline \multicolumn{6}{|l|}{ Phase II enzymes } \\
\hline N-Acetyltransferases & Decreased activity & & & & \\
\hline NAT2 & Decreased activity & Isoniazid & $\begin{array}{l}\text { Increased oxidative stress } \\
{[16]}\end{array}$ & ** & $\mathrm{n} / \mathrm{a}$ \\
\hline $\begin{array}{l}\text { Thiopurine } \\
\text { S-methyltransferase } \\
\text { (TPMT) }\end{array}$ & Decreased activity & $\begin{array}{l}\text { Azathioprine } \\
\text { Mesalazine } \\
\text { 6-Mercaptopurine } \\
\text { 6-Thioguanine }\end{array}$ & $\begin{array}{l}\text { ROS generation, causing } \\
\text { oxidative DNA } \\
\text { damage and mitochondrial } \\
\text { dysfunction }\left[15^{-1}\right]\end{array}$ & $\begin{array}{l}* * * \\
* * * \\
* \\
\text { No results }\end{array}$ & $\begin{array}{l}n / a \\
n / a \\
n / a \\
n / a\end{array}$ \\
\hline \multicolumn{6}{|l|}{$\begin{array}{l}\text { UDP Glucuronyltransferases } \\
\text { (UGTs) }\end{array}$} \\
\hline UGTI & $\begin{array}{l}\text { Decreased activity } \\
\text { Increased activity }\end{array}$ & Irinotecan & $\begin{array}{l}\text { Less scavenging of toxic } \\
\text { and reactive metabolites } \\
\text { [9] } \\
\text { Instable acyl derivatives } \\
\text { leading chemical protein } \\
\text { adducts with } \\
\text { electrophilic chemical } \\
\text { reactivity [9] }\end{array}$ & ** & low \\
\hline UGT2 & & & & & \\
\hline
\end{tabular}




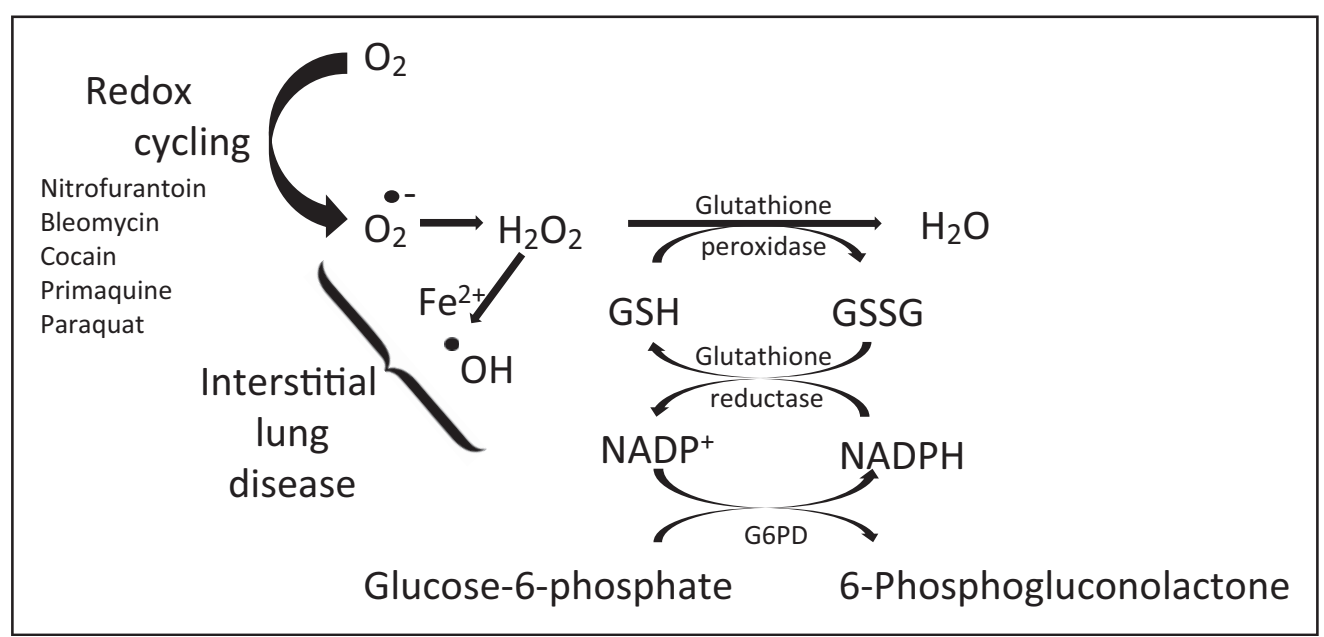

FIGURE 4. Redox cycling compounds generate superoxide anion-free radicals $\left(\mathrm{O}_{2}{ }^{--}\right)$. Upon dismutation $\mathrm{O}_{2}{ }^{\bullet-}$ is converted into hydrogen peroxide $\left(\mathrm{H}_{2} \mathrm{O}_{2}\right)$. In the presence of $\mathrm{Fe}^{2+}$ (which may originate from haem, upon red blood cell hemolysis) $\mathrm{H}_{2} \mathrm{O}_{2}$ can be transformed into the very reactive damaging hydroxyl radical $(\bullet \mathrm{OH}) . \mathrm{H}_{2} \mathrm{O}_{2}$ reduces to water $\mathrm{H}_{2} \mathrm{O}$ by glutathione peroxidase. In this reaction glutathione (GSH) provides the reducing equivalents and glutathione disulphide (GSSG) is formed. GSSG is reduced to GSH by glutathione reductase, which obtains its reducing equivalents from NADPH originating from the pentose phosphate pathway. In this pathway glucose-6-phospate dehydrogenase (G6PD) plays a crucial role.

with + for low, ++ for intermediate, and +++ for high presence [30]. Review of www.pneumotox.com and the latest literature review show (Table 1) that drugs associated with pulmonary toxicity are more often metabolized by CYP enzymes that have high presence or activity in the lung compared to drugs that are solely metabolized by CYPs with low presence in the lungs $\left[1^{-"}, 14\right]$.

\section{Acetaminophen / paracetamol}

Although acetaminophen (APAP) is mostly known for causing hepatotoxicity, the wide use of this drug

Table 2. Drugs to be avoided by G6PD-deficient patients [17]

\begin{tabular}{|c|c|}
\hline Drugs & Indication \\
\hline $\begin{array}{l}\text { Diaminodiphenyl } \\
\text { sulfone (Dapsone) }\end{array}$ & Leprosy \\
\hline Flutamide & Prostate cancer \\
\hline Furazolidone & $\begin{array}{l}\text { Largely forbidden as } \\
\text { human antibiotic }\end{array}$ \\
\hline Methylene blue & Methemoglobinemia \\
\hline Nitrofurantoin & $\begin{array}{l}\text { Urinary tract infections } \\
\text { (among others) }\end{array}$ \\
\hline Phenazopyridine & Analgesic \\
\hline Primaquine & Malaria \\
\hline Rasburicase & Excess uric acid \\
\hline Sulfacetamide & Infections \\
\hline Sulfanilamide & Infections \\
\hline
\end{tabular}

justifies drawing the attention for its rare pulmonary toxicity. It is a commonly used medicine for relieving pain and reducing fever in adults and children [31]. The majority of APAP is metabolized in the liver and after glucuronidation and sulfation safely excreted. However, a fraction of APAP is metabolically activated in the liver by CYP2E1, CYP3A4, and CYP1A2, to the pro-oxidant metabolite $\mathrm{N}$-acetyl-p-benzoquinone-imine (NAPQI) [32]. These CYPs are expressed in the respiratory tract, suggesting that similar metabolic activation as in the liver may also occur in the lungs [33]. Polymorphisms that accelerate the forming of NAPQI may lead to enhanced toxicity [34]. There are two hypotheses for the mechanisms of lung injury by NPAQI. The first one suggests that because of NAPQI is highly reactive, it causes cellular oxidative stress, and may covalently bind to cellular macromolecules [35]. The second hypothesis suggests a more specific mechanism of APAP-induced lung disease and proposes neurogenic inflammation. Nassini et al. [36-40] suggested that inflammation develops in the lungs after APAP treatment because of activation of the transient receptor potential ankyrin 1 (TRPA1) channel in peptidergic neurons by NAPQI. The TRPA1 hypothesis may be more biologically plausible; however, the evidence for this hypothesis is also preliminary and both models should be further explored.

\section{THIOPURINE S-METHYLTRANSFERASE}

TPMT polymorphisms lead to an almost 50-fold variation in enzyme activity between individuals. TPMT 


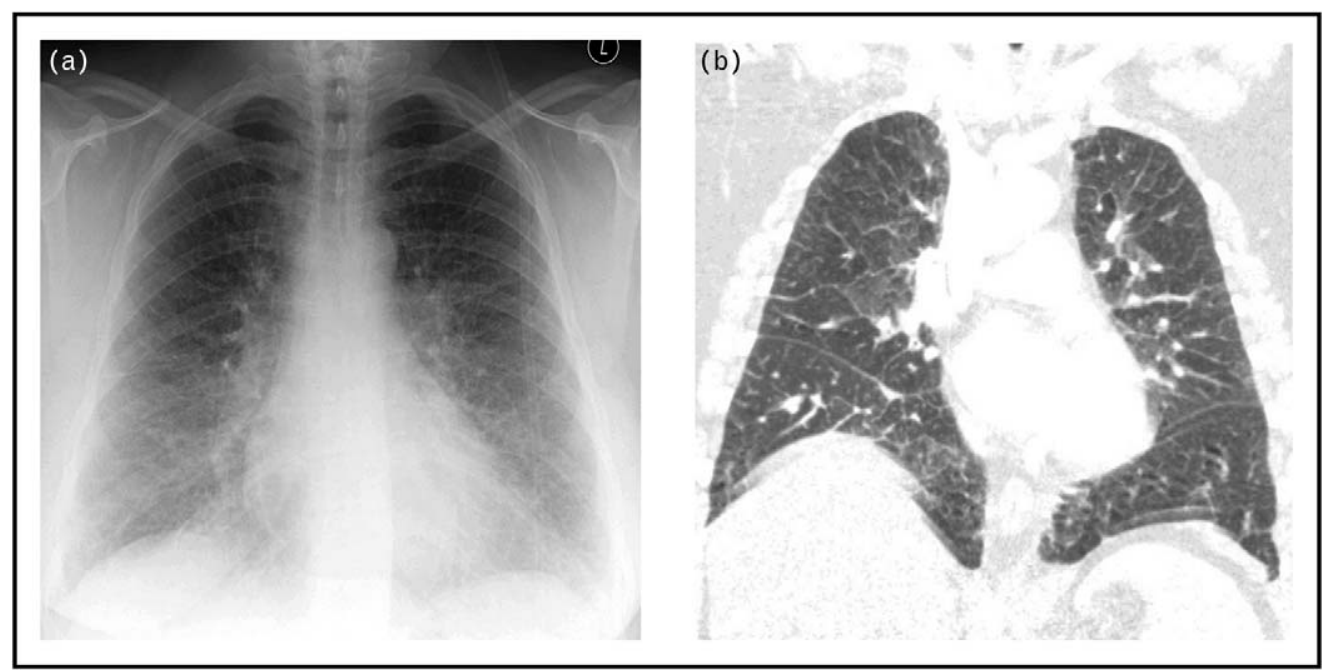

FIGURE 5. An example of nitrofurantoin-induced pneumonitis: (a) chest X-ray shows a diffuse reticular pattern: (b) Highresolution computed tomography (coronal slice) confirms this reticular pattern, which is caused by thickening of the interlobular septa.

catalyzes the transfer of the methyl-group of S-adenosylmethionine to the thiol-group on the thiopurine molecule. Methylation of thiopurines is one of the detoxification reactions in thiopurine metabolism. Variations in response to thiopurine drug therapy are mainly caused by TPMT polymorphism. Adverse effects of the thiopurines, 6-mercaptopurine, and azathioprine include bone marrow suppression, which is of major concern, occurring in $2-5 \%$ of inflammatory bowel disease patients. The risk of thiopurine induced myelosuppression is increased in patients with TPMT deficiency. Liver toxicity occurs in 3-10\% of azathioprine exposed patients with hypersensitivity, an idiosyncratic cholestatic reaction, or endothelial cell damage and results in drug withdrawal. A number of different factors have been reported to be linked to thiopurine-induced hepatotoxicity including higher concentrations of methylated metabolites and mitochondrial injury associated with glutathione depletion. Thiopurines are known to induce oxidative stress, especially in mitochondria, resulting in mitochondrial dysfunction and activation of stress activated protein kinase pathways. Azathioprine-induced oxidative stress causes tricarboxylic acid cycle dysfunction by depleting crucial mitochondrial enzymes. The metabolite 6-thioguanine nucleotide (6-TGN), a thiopurine metabolite, is also known to incorporate into mitochondrial DNA (mtDNA), where it is rapidly oxidized and inhibits mtDNA replication causing decreased mitochondrial protein concentrations and loss of mitochondrial function. A recent study in cultured human lymphoblasts proposed ROS generation, resulting in oxidative DNA damage and mitochondrial dysfunction as the mechanism responsible for thioguanine induced cytotoxicity. Thiopurine induced alterations in the expression of genes involved in protein and ATP-biosynthesis. When mice were treated with 6-mercaptopurine, significant alterations were observed in the expression of genes associated with abnormal lipid metabolism, inflammatory responses, oxidative stress, ATP depletion, and cell death [41]. Although several cases of azathioprine induced ILD are known, so far, in only one case TPMT deficiency has been associated with pulmonary toxicity $[14,42]$.

In case of an azathioprine indication, also used as treatment for certain ILDs, testing TPMT variants involved in azathioprine metabolism is advised before starting treatment [42-44]. In the Unites States of America, drug labels for azathioprine now include information on TPMT polymorphisms and recommend determining patients' phenotype or genotype prior to drug treatment [45].

\section{DISCUSSION}

Genetic variations in drug metabolizing enzymes may enhance the causation of DI-ILD by inducing the forming of ROS or reactive metabolites (phase I) or by reducing the scavenging of these ROS or reactive metabolites (phase II). We cautiously want to mark that drugs that are solely metabolized by CYP1A (low presence in the lungs), and known for other idiosyncratic adverse drug reactions, such as clozapine, are less associated with DI-ILD than drugs that are metabolized by CYPs with high presence in the lungs such as CYP3A. It was expected that drugs that undergo redox cycling would be well known for causing DIILD, but besides nitrofurantoin and cocaine, no other 
drugs that should be avoided in G6PD-deficiency had a five-star code in www.pneumotox.com [14]. We must, however, keep in mind that nitrofurantoin and cocaine are far more widely used than the other drugs. Although our findings may point to an association between genetic variation of metabolizing enzymes and the occurrence of DI-ILD it has thus far not been extensively researched, resulting in low grades of evidence and enforcing us to review older publications, however, from a novel perspective.

Both genetic and nongenetic information is important in the susceptibility, development, cause, and treatment response of diseases. The more we know about a patient's genes and context, the better disease management decisions can be made [46]. The ability to identify individuals who are susceptible to adverse drug reactions has the potential to reduce the personal and population costs of drug-related morbidity and the potential to attribute to the patients' safety. Genotyping should be considered to identify patients that might be at risk of severe toxic responses to environmental, pharmacological, herbal remedy, and/or nutritional stimuli, in order to guide appropriate individual dosage(s) [47]. Some patients will continue to react unpredictably to therapy even though, according to obtained test results, problems were not expected. This variability in drug response among patients is multifactorial and include extrinsic factors like environmental aspects, comedication, nutritional status, smoking and alcohol consumption, and intrinsic factors that affect the disposition (absorption, distribution, metabolism, and excretion) of individual drugs.

There are an increasing number of examples where pharmacogenetic studies have indicated that genetic testing prior to treatment may be useful either for setting the individual dose or in choosing a certain drug [48,49,50"']. Genetic screening prior to drug prescription may potentially prevent serious adverse effects such as diffuse alveolar hemorrhage (DAH) or DI-ILD [51"',52"]. The results obtained by genetic testing appeared to be useful in disease management, because of the prognostic value of the absence or presence of specific polymorphisms. An association with vitamin K epoxide reductase complex 1 (VKORC1) and/or CYP2C9 variant alleles might even be a risk factor for the development or exacerbation of idiopathic pulmonary fibrosis [51"']. Furthermore, it was accentuated that in DAH cases early recognition of the presence of one of the studied polymorphisms is important, because of a potential lethal outcome and the fact that simple vitamin $\mathrm{K}$ supplementation can be life-saving [52"]. Genetic variations are, of course, not limited to drug metabolizing enzymes like the substrates of these enzymes are not limited to drugs. Needless to say, many more substances are associated with the occurrence of ILD. The redox cycling herbicide paraquat is well known and another striking example is 4-ipomeanol, a toxin produced by moldy sweet potatoes (Ipomoea batatas) caused by postharvest diseases, the most common is infection with the fungus Fusarium solani. Ingested molded sweet potatoes by livestock causes interstitial pneumonia. The extrahepatic CYP enzyme CYP4B1, present in lung tissue, activates 4-ipomeanol to a reactive intermediate that reacts with nitrogen or sulfur nucleophiles and leads to toxicity [53-55].

It has also been suggested that in the treatment of IPF, clinical meaningful precision medicine might be possible with the antioxidant $\mathrm{N}$-acetylcysteine by taking into account polymorphism within TOLLIP [56].

\section{CONCLUSION}

Although genetic variations in drug metabolizing enzymes may play an important role in the individual response on drug medication, there are many other factors involved such as age, renal and liver function, concomitant diseases, nutritional status, smoking and alcohol consumption. A 'one-size-fitsall' approach to medicine is based on broad population averages. The advent of personalized medicine is moving us closer to more precise, predictable, and powerful healthcare that is customized for the individual patient. Growing understanding of genetics and genomics provide many advantages in tailoring healthcare to each person's unique genetic make-up which may result in better disease prevention, more accurate diagnoses, safer drug prescriptions, and more effective treatments. It appears that genetic variations in metabolizing enzymes are able to enhance the drivers of DI-ILD. This paves the way for the potential usefulness of personalized medicine by genotyping and aiming to improve efficacy, tolerability, and drug safety. With this, knowledge on pharmacogenetics may finally serve as a predictor of toxicity and clinical response.

There is still a need for well designed prospective clinical trials that measure patient-oriented outcomes of selected genomic applications, and studies that evaluate the role of genomic variations in disease susceptibility, predicting prognosis, treatment response, and in tailoring drug treatment for individual patients. These investigations are aimed to help bridge the gap between 'personalized' and 'evidence-based' medicine.

\section{Acknowledgements}

None. 


\section{Financial support and sponsorship}

The preparation of this review was supported by a grant of the ILD care foundation: www.ildcare.nl. This study was not industry-sponsored.

\section{Conflicts of interest}

There are no conflicts of interest.

\section{REFERENCES AND RECOMMENDED READING}

Papers of particular interest, published within the annual period of review, have been highlighted as:

- of special interest

- of outstanding interest

1. Skeoch S, Weatherley $\mathrm{N}$, Swift $\mathrm{AJ}$, et al. Drug-induced interstitial lung - disease: a systematic review. J Clin Med 2018; 7:pii: E356.

This is a recent review about drug-induced interstitial lung diseases (DI-ILD). Overall high-quality evidence in DI-ILD is lacking, and the current review will inform larger prospective studies to investigate the diagnosis and management of DI-ILD.

2. Roden $A C$, Camus P. latrogenic pulmonary lesions. Semin Diagn Pathol - 2018; 35:260-271.

In this review, the authors stress the importance that clinicians and pathologists are aware of these potential adverse effects of drugs, radiation, and medical devices and raise the possibility of drug-induced lung toxicity after exclusion of other differential diagnoses. Early intervention to a drug-induced lung toxicity might prevent progression of side effects and permanent changes.

3. Flieder DB, Travis WD. Pathologic characteristics of drug-induced lung disease. Clin Chest Med 2004; 25:37-46.

4. Travis WD, Costabel U, Hansell DM, et al. An official American Thoracic Society/European Respiratory Society statement: update of the international multidisciplinary classification of the idiopathic interstitial pneumonias. Am J Respir Crit Care Med 2013; 188:733-748.

5. Weatherley ND, Eaden JA, Stewart NJ, et al. Experimental and quantitative imaging techniques in interstitial lung disease. Thorax 2019. [Epub ahead of print]

6. Wuyts WA, Cavazza A, Rossi G, et al. Differential diagnosis of usual interstitial pneumonia: when is it truly idiopathic? Eur Respir Rev 2014; 23:308-319.

7. Matsuno $O$. Drug-induced interstitial lung disease: mechanisms and best diagnostic approaches. Respir Res 2012; 13:39.

8. Ryrfeldt A. Drug-induced inflammatory responses to the lung. Toxicol Lett 2000; 112-113:171-176.

9. Castell JV, Donato MT, Gomez-Lechon MJ. Metabolism and bioactivation of toxicants in the lung. The in vitro cellular approach. Exp Toxicol Pathol 2005; 57(Suppl 1):189-204

10. Israel-Biet D, Labrune S, Huchon GJ. Drug-induced lung disease: 1990 review. Eur Respir J 1991; 4:465-478.

11. Nadeem A, Al-Harbi NO, Ahmad SF, et al. Glucose-6-phosphate dehydrogenase inhibition attenuates acute lung injury through reduction in NADPH oxidasederived reactive oxygen species. Clin Exp Immunol 2018; 191:279-287.

12. Qi $S$, den Hartog GJ, Bast A. Superoxide radicals increase transforming growth factor-beta1 and collagen release from human lung fibroblasts via cellular influx through chloride channels. Toxicol Appl Pharmacol 2009; 237:111-118.

13. den Hartog GJ, Qi S, van Tilburg JH, et al. Superoxide anion radicals activate hepatic stellate cells after entry through chloride channels: a new target in liver fibrosis. Eur J Pharmacol 2014; 724:140-144.

14. Pneumotox online. The drug-induced respiratory disease. http://www.pneumotox.com [updated 24 March 2019]. [Accessed 29 March 2019]

15. $\mathrm{Ye} \mathrm{H}$, Nelson LJ, Gomez Del MM, et al. Dissecting the molecular pathophysiology of drug-induced liver injury. World J Gastroenterol 2018; 24:1373-1385.

This review describes mechanisms of intrinsic and idiosyncratic drug-induced hepatotoxicity. Also the important role of innate and adaptive immune responses in the occurrence of idiosyncratic drug toxicity is discussed. Mechanisms described for the liver are also applicable for the lung.

16. Weinshilboum R. Inheritance and drug response. N Engl J Med 2003; 348:529-537.

17. Evans WE, Relling MV. Pharmacogenomics: translating functional genomics into rational therapeutics. Science 1999; 286:487-491.

18. McLeod HL, Krynetski EY, Relling MV, et al. Genetic polymorphism of thiopurine methyltransferase and its clinical relevance for childhood acute lymphoblastic leukemia. Leukemia 2000; 14:567-572.

19. Amstutz U, Froehlich TK, Largiader CR. Dihydropyrimidine dehydrogenase gene as a major predictor of severe 5 -fluorouracil toxicity. Pharmacogenomics $2011 ; 12: 1321-1336$
20. Wijnen PA, Drent M, Nelemans PJ, et al. Role of cytochrome P450 polymorphisms in the development of pulmonary drug toxicity: a case-control study in the Netherlands. Drug Saf 2008; 31:1125-1134.

21. Bast A, Hanekamp JC. Toxicology: what everyone should know. Academic Press, Elsevier; 2017.

22. Haenen GR, Bast A. Glutathione revisited: a better scavenger than previously thought. Front Pharmacol 2014; 5:260.

23. Wijnen PA, Verschakelen JA, Bast $A$, et al. Diffuse alveolar hemorrhage in coumarin users: a fibrosing interstitial pneumonia trigger? Lung 2013; 191:53-59.

24. Bast $A$, Weseler $A R$, Haenen $G R$, et al. Oxidative stress and antioxidants in interstitial lung disease. Curr Opin Pulm Med 2010; 16:516-520.

25. Veith $C$, Drent $M$, Bast $A$, et al. The disturbed redox-balance in pulmonary fibrosis is modulated by the plant flavonoid quercetin. Toxicol Appl Pharmacol 2017; 336:40-48.

26. Drent $M$, Wijnen $P$, Bast $A$. Interstitial lung damage due to cocaine abuse: pathogenesis, pharmacogenomics and therapy. Curr Med Chem 2012; 19:5607-5611.

27. Vasquez-Vivar J, Augusto O. Hydroxylated metabolites of the antimalarial drug primaquine. Oxidation and redox cycling. J Biol Chem 1992; 267: 6848-6854.

28. Bubp J, Jen M, Matuszewski K. Caring for glucose-6-phosphate dehydrogenase (G6PD)-deficient patients: implications for pharmacy. P T 2015; 40:572-574.

29. Wilkinson GR. Drug metabolism and variability among patients in drug response. N Engl J Med 2005; 352:2211-2221.

30. Wijnen $P A$, Bekers $O$, Drent M. Relationship between drug-induced interstitial lung diseases and cytochrome P450 polymorphisms. Curr Opin Pulm Med 2010; $16: 496-502$

31. Baudouin SV, Howdle $P, O^{\prime} G$ rady JG, et al. Acute lung injury in fulminant hepatic failure following paracetamol poisoning. Thorax 1995; 50:399-402.

32. McGill MR Jaeschke $H$. Metabolism and disposition of acetaminophen: recent advances in relation to hepatotoxicity and diagnosis. Pharm Res 2013; 30:2174-2187.

33. Ding $X$, Kaminsky LS. Human extrahepatic cytochromes $P 450$ : function in xenobiotic metabolism and tissue-selective chemical toxicity in the respiratory and gastrointestinal tracts. Annu Rev Pharmacol Toxicol 2003; 43:149-173.

34. Utkarsh D, Loretz C, Li AP. In vitro evaluation of hepatotoxic drugs in human hepatocytes from multiple donors: Identification of P450 activity as a potential risk factor for drug-induced liver injuries. Chem Biol Interact 2016; 255:12-22.

35. Jaeschke H, McGill MR, Ramachandran A. Oxidant stress, mitochondria, and cell death mechanisms in drug-induced liver injury: lessons learned from acetaminophen hepatotoxicity. Drug Metab Rev 2012; 44:88-106.

36. Kennon-McGill S, McGill MR. Extrahepatic toxicity of acetaminophen: critical evaluation of the evidence and proposed mechanisms. J Clin Transl Res 2018; 15:3.

37. Breen $\mathrm{K}$, Wandscheer $\mathrm{JC}$, Peignoux $\mathrm{M}$, et al. In situ formation of the acetaminophen metabolite covalently bound in kidney and lung. Supportive evidence provided by total hepatectomy. Biochem Pharmacol 1982; $31: 115-116$.

38. Bartolone JB, Beierschmitt WP, Birge RB, et al. Selective acetaminophen metabolite binding to hepatic and extrahepatic proteins: an in vivo and in vitro analysis. Toxicol Appl Pharmacol 1989; 99:240-249.

39. Bulera SJ, Cohen SD, Khairallah EA. Acetaminophen-arylated proteins are detected in hepatic subcellular fractions and numerous extra-hepatic tissues in CD-1 and C57B1/6J mice. Toxicology 1996; 109:85-99.

40. Nassini $R$, Materazzi $S$, Andre $E$, et al. Acetaminophen, via its reactive metabolite $\mathrm{N}$-acetyl-p-benzo-quinoneimine and transient receptor potential ankyrin-1 stimulation, causes neurogenic inflammation in the airways and other tissues in rodents. FASEB J 2010; 24:4904-4916.

41. Misdaq $\mathrm{M}$, Ziegler $\mathrm{S}$, von Ahsen $\mathrm{N}$, et al. Thiopurines induce oxidative stress in T-lymphocytes: a proteomic approach. Mediators Inflamm 2015; 2015: 434825.

42. Bakker $J A$, Bierau J, Drent $M$. Therapeutic regimens in interstitial lung disease guided by genetic screening: fact or fiction? Eur Respir J 2007; 30:821-822.

43. Schutz E, von AN, Oellerich M. Genotyping of eight thiopurine methyltransferase mutations: three-color multiplexing, 'two-color/shared' anchor, and fluorescence-quenching hybridization probe assays based on thermodynamic nearest-neighbor probe design. Clin Chem 2000; 46:1728-1737.

44. Baker DE. Pharmacogenomics of azathioprine and 6-mercaptopurine in gastroenterologic therapy. Rev Gastroenterol Disord 2003; 3:150-157.

45. Daly AK. Individualized drug therapy. Curr Opin Drug Discov Devel 2007; 10:29-36.

46. Varmus $\mathrm{H}$. Ten years on-the human genome and medicine. $\mathrm{N}$ Engl J Med 2010; 362:2028-2029.

47. Ozer N, Cam N, Tangurek B, et al. The impact of CYP2C9 and VKORC1 genetic polymorphism and patient characteristics upon warfarin dose requirements in an adult Turkish population. Heart Vessels 2010; 25:155-162.

48. Imatoh T, Sai K, Saito Y. Pharmacogenomic information in the warning section of drug labels: a comparison between labels in the United States and those in five other countries/regions. J Clin Pharm Ther 2018; 43:493-499. 
49. Picard N, Boyer JC, Etienne-Grimaldi MC, et al. Pharmacogenetics-based personalized therapy: Levels of evidence and recommendations from the French Network of Pharmacogenetics (RNPGx). Therapie 2017; 72:185-192.

50. Cousin MA, Matey ET, Blackburn PR, et al. Pharmacogenomic findings from

- clinical whole exome sequencing of diagnostic odyssey patients. Mol Genet Genomic Med 2017; 5:269-279.

In this study, the role of pharmacogenomics has been reported in a cohort of diagnostic odyssey patients and the likely benefit of these results on patient medication management in the clinical care for conscientious interpretation and management to ensure appropriate prescribing decisions can be made.

51. Drent $M$, Wijnen $P$, Bast $A$. Pharmacogenetic variants and vitamin $K$ defi-

- ciency: a risk factor or trigger for fibrosing interstitial pneumonias? Curr Opin Pulm Med 2018; 24:287-295.

This review highlights that in personalized medicine, when therapy is targeted towards the need of individual patients with various interstitial pneumonia disease phenotypes, testing for CYP2C9, CYP2C19, and/or vitamin $\mathrm{K}$ epoxide reductase complex 1 variants should be included to achieve a favorably response without serious adverse reactions like DAH.
52. Wijnen $P$, Drent $M$, Bekers $O$, et al. VKORC1 and CYP2C9 polymorphisms: a - case report in a dutch family with pulmonary fibrosis. Int J Mol Sci 2019; 20:pii: E1160.

This case report describes the promising value of genotyping in fibrotic lung diseases and role of pharmacogenomics in clinical practice.

53. Parkinson OT, Teitelbaum AM, Whittington D, et al. Species differences in microsomal oxidation and glucuronidation of 4-ipomeanol: Relationship to target organ toxicity. Drug Metab Dispos 2016; 44: 1598-1602.

54. Baer BR, Rettie AE, Henne KR. Bioactivation of 4-ipomeanol by CYP4B1: adduct characterization and evidence for an enedial intermediate. Chem Res Toxicol 2005; 18:855-864.

55. Wu W, Li Y. Lung injury caused by paraquat poisoning results in increased interleukin-6 and decreased microRNA-146a levels. ExpTher Med 2018; 16:406-412.

56. Oldham JM, Ma S-F, Martinez FJ, et al. TOLIP, MUC5B, and the response to $\mathrm{N}$-acetylcysteine among individuals with idiopathic pulmonary fibrosis. Am J Respir Crit Care Med 2015; 192:1475-1482. 